\title{
The Social Representations of Health: A Common Symbolic Place
}

\section{Evangelia Briseniou1, Nikolaos Skenteris' ${ }^{1}$, Chrissi Hatzoglou1, Elena Dragioti ${ }^{2,3}$ (D), Epaminondas Diamantopoulos ${ }^{2}$, George D. Tsitsas ${ }^{4}$, Mary Gouva ${ }^{2}$}

\author{
${ }^{1}$ Faculty of Medicine, School of Health Sciences, University of Thessaly, Larisa, Greece \\ ${ }^{2}$ Department of Nursing, School of Health Sciences, University of Ioannina, Ioannina, Greece \\ ${ }^{3}$ Pain and Rehabilitation Centre and Department of Health, Medicine and Caring Sciences, Linköping University, \\ Linköping, Sweden \\ ${ }^{4}$ Counseling Centre, Harokopio University, Athens, Greece \\ Email:briseniou@yahoo.gr,nskenter@med.uth.gr,chatz@med.uth.gr,elena.dragioti@liu.se, \\ epdiamantopoulos@yahoo.gr,gtsitsas@hua.gr,gouva@uoi.gr
}

How to cite this paper: Briseniou, E., Skenteris, N., Hatzoglou, C., Dragioti, E., Diamantopoulos, E., Tsitsas, G. D., \& Gouva, M. (2020). The Social Representations of Health: A Common Symbolic Place. Creative Education, 11, 2176-2192. https://doi.org/10.4236/ce.2020.1110157

Received: September 3, 2020

Accepted: October 26, 2020

Published: October 29, 2020

\section{Copyright $\odot 2020$ by author(s) and} Scientific Research Publishing Inc. This work is licensed under the Creative Commons Attribution International License (CC BY 4.0).

http://creativecommons.org/licenses/by/4.0/ (c) (i) Open Access

\begin{abstract}
Background: There are relatively limited studies exploring the relationship between social representations and language although language is a system that lives in the symbolic universe of the people, where every word has the dual nature of both signified and signifier. Aim: This study aimed to identify and investigate the common social representation of eight words representing health and lifestyle factors in a convenience sample of 288 adults from general population living in Greece. Methods: The participants were asked to express three consecutive words associated with eight different life experiences using the free association method. The frequency of all word combinations was calculated regardless of the position that they have been said and the undirected graph of the words was created. The position of each word in the graph and its relationship with the other words of the same word group was characterized by its centrality. Repeated measures analysis of variance was applied to investigate the word position and category effects in the centrality of the spoken word controlling for gender, age, family situation, and educational level. Results: In all eight-word categories, a decreasing order of centrality was observed in the spoken words a finding that supports the hypothesis that there are common reflections on the language of the representations concerning the questioned life experiences. No significant differences were reported for sociodemographic factors highlighting the character of language as a social symbolic system adopted by all members of society regardless of their particular characteristics. Conclusions: We concluded that the understanding of the relationship between social representations of health and the language is in-
\end{abstract}


trinsically related to the behavior that language as a common way of communication can bring to psychosomatic health.

\section{Keywords}

Social Representations, Language, Health, Psychology, Health Attitudes

\section{Introduction}

Researchers in many disciplines have developed techniques for studying language, formulating messages and narratives, and how language reflects attitudes, beliefs, and values. An array of the extensive theoretical and methodological vocabulary of language analysis can begin with the language itself (Foucault, 1971, 1972) and include other terms such as deconstruction (Derrida, 1981), interpretive (Geertz, 2000), reference framework (Lakoff \& Johnson, 2003). As the field of discourse analysis has developed, approaches have been devised that are specific to different types of narratives (Alasuutari, 1995).

Language is the place where communities meet to share their important meanings and describe common life experiences. But how one could enlighten the existence and the extent of domination of such common language representations?

One well-recognized way is to use the theory of social representations. Social representations are in fact a "theory of social knowledge". The concept of social representations was initially proposed by Serge Moscovici, as a searching tool to explore psychoanalysis viewpoints in 1950s French society (Moscovici, Doise, \& Dulong, 1972). According to Moscovici, social representations are simply a part of a "thinking society" in which the thinking is acted loud-mouthed. Social reality is constructed and negotiated through the language, activities, and interactions of individuals and groups, which are part and parcel of wider collective practices and belief systems lived out through the structure of society and its institutions (Moscovici, 1984; Moscovici \& Hewstone, 1984; Moscovici et al., 1972). Each social representation is organised around a central nucleus which determines both its meaning and its organisation (Abric, 1988).

The social representations of health and illness were first studied by Herzlich (1973) where it was found that health does not need any explanation as opposed to illness which needs some explanation. According to Cardoso \& Gormes (2000) "health concern is a human-born phenomenon" which can bring a dialogue among different disciplines such as language, social representation theory, and health psychology (Joffe, 1995). For example, the work of Flick et al. (1998) focused on explicit areas of social representations by categorizing physicians' and nurses' subjective definitions of health and provided an overview of how different professional groups conceptualize health and illness. Earlier Murray (1993) explored how people exchange stories about health and illness in their everyday 
interactions and he concluded that it is through the exchange of these stories via language that a community creates a social representation. In a more recent article Murray (2002) also argued that, through the telling of narratives, a community is engaged in the process of creating a social representation while at the same time drawing upon a broader collective representation. However, research into the correlations of the biological processes of health, illness, and lifestyle factors with language through social representations has not been studied to date in the literature.

Thus, any attempt to approach the aforementioned questions presupposes the acceptance of a hypothesis about the structure of the language. The view adopted by the present article is the one initiated by Ferdinand de Saussure and Jacques Derrida, culminating at Jacques Lacan's (1977) work that language is a system that lives in the symbolic universe of the subject, where every word has the dual nature of both signified and signifier. In other words, each word can stand for an object of the physical or intellectual world having also the ability to trigger the birth of another word according to the subject's internal semantic structure.

This article aims to investigate the social representations that are connected with eight common life aspects concerning both the biological nature of a human

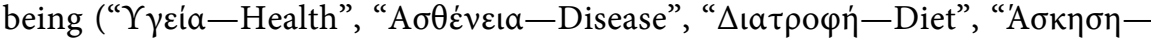

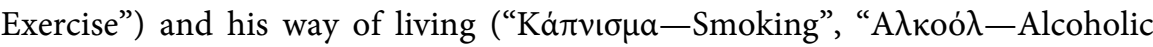

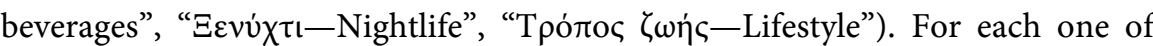
the categories, the participants were given the corresponding stimulus word and asked to provide quickly via free association three words which spontaneously come into their mind without having any grammatical limitations concerning the type of the words.

The research goal of the study is to find whether there are differences to the acceptance of common social representation among the eight selected categories, whether word position has an effect on the personal character of the chosen words, and whether those words are affected by the object's sociodemographic characteristics (age, gender, educational level, and family status).

\section{Methods}

\subsection{Participants and Study Design}

This cross-sectional study was carried out at spring and summer of 2019. Using a snowball sampling method, we invited individuals via online survey from general population living in 20 different regions of Greece. The main source of the sample was the public university of each region. However, the sampling was expanded to include also using snowball method selected individuals from the general population of each region. The sample included only individuals who were born in Greece and were fluent in Greek Moreover, inclusion criteria were age greater than 18 years old and graduate at least from Primary school. Exclusion criteria were any current medical diagnosis and history of mental disorders requiring psychiatric or other medication. All participants were in- 
formed that reports were confidential and the participation in the study was voluntary.

Finally, two hundred ninety-four Greek adults participated in the study, 110 men (37.4\%) and 184 women (62.6\%) aged 19 to $85,(\mathrm{M}=44.7, \mathrm{SD}=12.8)$. The majority was married $(\mathrm{N}=169,57.5 \%)$ and University graduates $(\mathrm{N}=198$, $67.3 \%)$.

\subsection{Research Process}

For each participant, a socio-demographic questionnaire was completed. Further, each participant was given one questionnaire and was asked to complete three words for the eight categories of "diet, exercise, smoking, alcoholic beverage, nightlife, lifestyle, disease, and health" using the method of free association. We asked the participants to write everything that came to mind spontaneously when they thought about these categories to access the most commonly shared elements representing these categories for them. The participants were instructed to fill out the questionnaire individually and send it back via email or post. Since the individuals would give (3) words per category, which means a large number of words, those words that would appear at a rate of $\geq 7.5 \%$ were considered statistically significant in terms of frequency, for two reasons; a) the number of words of the whole sample would be very large and by determining this percentage the statistical measurements were facilitated and b) in the measurements were included words with a lower frequency of occurrence concerning others, but strongly contributing to the formation of the social representation of the individuals.

\subsection{Data Preparation}

Each word was typed separately in the datasheet. Words represented the same meaning in the Modern Greek language were grouped with a hyphen between them

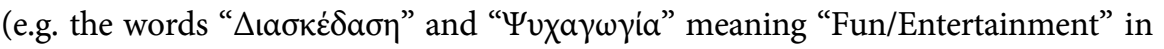
Modern Greek formulate the compound word " $\Delta \iota \alpha \sigma \kappa \varepsilon \delta \delta \sigma \eta \eta-\Psi v \chi \alpha \gamma \omega \gamma i \alpha$ ” since it was considered that they express a similar underlying perception). The complete list of words that was grouped is presented in Table A1 of the Appendix. This procedure although subjective, was necessary since the independent participation of words with small conceptual difference and large frequency differences would hide the influence of the construct described by them.

\subsection{Free Association Data Handling}

Free association data are frequently analyzed via "rank-frequency" and "ranked associations" methods, where each word is characterized by its frequency and its spontaneous appearance ranking. Then, the congruence of the two criteria is assumed to constitute an indicator of the centrality of an element (Abric, 1994a). A variation of the "rank-frequency" method is the "ranked associations" method where the subject is asked to classify the words in accordance to the importance they allocate, information which is then used to detect the most important words 
concerning the ability to represent the object being studied (Dany, Urdapilleta, \& Monaco, 2015).

In the present study, an undirected graph representation was used as an option that allows the analysis of the collected words, in a way that takes into account both the frequency of occurrence and the frequency of combinations with the other words. The frequency of each word represents the social agreement about the power of the word to describe the initial representation whereas the interconnections among the words reveal the most important of them. The undirected nature of the graph was chosen in favor of the directed graph alternative in accordance to the assumption that the spontaneously selected words are attempts of the subject to describe symbolic representations that are internally related with the main representation defined by the original stimulus word, without having a clear order, that is, without any cause-and-effect relationship (Figure 1).

The authority centrality index was calculated for each word as a measure incorporating both frequency of appearance and frequency of connections with other words, indicating each word's relative position to the centre of the graph (Bonacich \& Paulette, 2001).

\subsection{Statistical Analysis}

The frequency of all combinations between the first and the second word as well as between the second and the third word was counted and the aggregated list of all word combinations was used to define the symmetric adjacency matrix from which the undirected graph of words was created. Then, the authority centrality index of each word was computed as it has been proposed in the literature

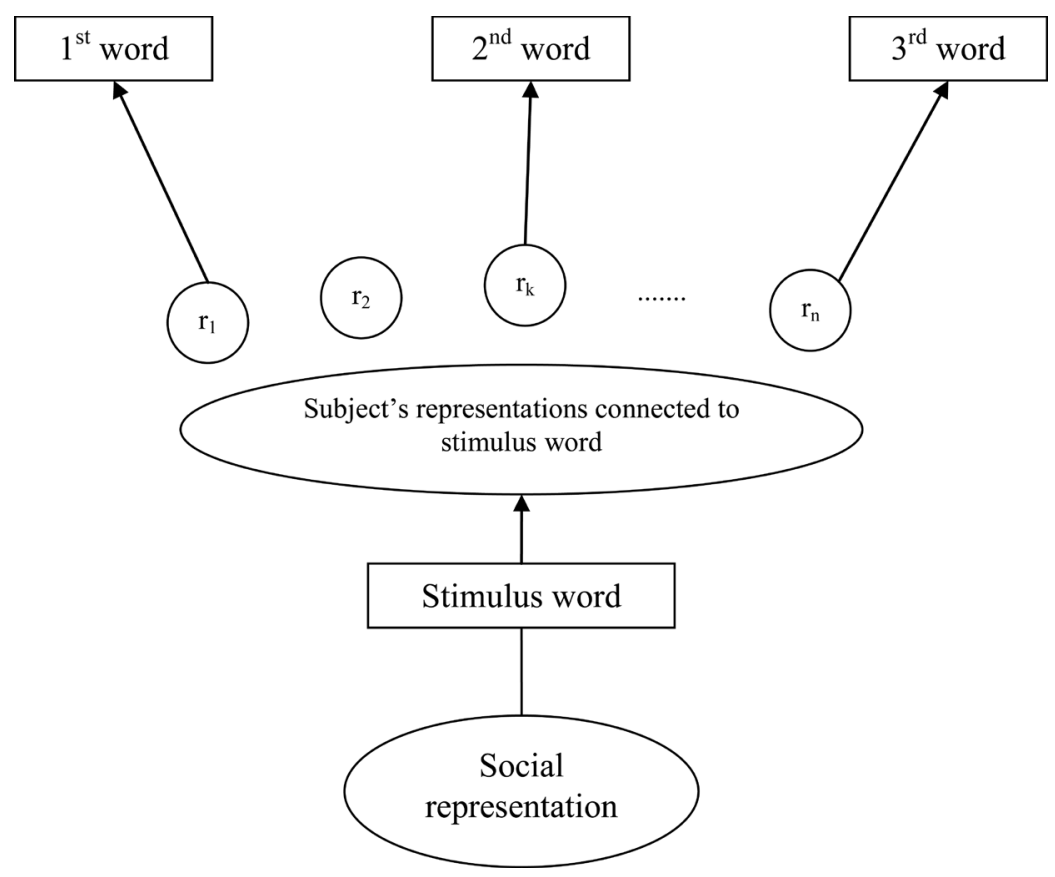

Figure 1. The words reflect the social represention. 
(Bonacich \& Lloyd, 2001).

A two way repeated measures analysis of variance (2-way repeated ANOVA) was applied in order to investigate whether there are significant differences to the centrality of the three words between the eight word categories as well as between the three measurements controlling for an interaction with gender, age, family situation and educational level. Mauchly's test of sphericity was used to test the necessary assumption of sphericity and Greenhouse-Geisser correction was applied whenever the sphericity assumption was not met. Post-hoc paired samples t-test was applied to find homogeneous measurements with adjusted level of rejection according to Bonferroni correction.

All data were analyzed using SPSS statistical package (version 21) and R statistical language (RC Team, 2013) equipped with tidyverse and tidygraph packages (Wickham et al., 2019).

\section{Results}

Table 1 shows the number of different words gathered for each category and the mean centrality of the three spoken words as well as the mean centrality of the three measurements for each respondent as a simple measure indicating the relevant position between the different categories in terms of the variability of the selected words. The category of words related to nightlife had the largest variety of words (93), while words concerning smoking had the smallest variety (64). The word graphs for the eight word categories are presented in the Figure A1 and the Figure $\mathrm{A} 2$ of the Appendix. In all eight-word categories a decreasing order of centrality was observed. The five words with the largest centralities for each one category and the corresponding cumulative frequency of appearance in first, second and third positions are presented in the Table A2 of the Appendix.

Mauchly's test indicated that the sphericity assumption was met for the interaction of position and category $\left(\mathrm{W}=0.600, c^{2}(104)=122.3, p=0.107\right)$ and position factor $\left(\mathrm{W}=0.994, \mathrm{c}^{2}(2)=1.361, p=0.506\right)$ but it was rejected for the Table 1 . Mean centrality for $1^{\text {st }}, 2^{\text {nd }}$ and $3^{\text {rd }}$ word.

\begin{tabular}{cccccc}
\hline & \multirow{2}{*}{$\begin{array}{c}\text { Number of } \\
\text { different words }\end{array}$} & \multicolumn{3}{c}{ Centrality (M (SD)) } & \multirow{2}{*}{ Total mean $^{1}$} \\
\cline { 3 - 5 } & & $1^{\text {st }}$ word & $2^{\text {nd }}$ word & $3^{\text {rd }}$ word & \\
\hline Diet & 83 & $0.68(0.31)$ & $0.58(0.29)$ & $0.47(0.31)$ & $0.58(0.19)$ \\
Exercise & 80 & $0.62(0.29)$ & $0.51(0.27)$ & $0.42(0.30)$ & $0.52(0.17)$ \\
Smoking & 64 & $0.63(0.23)$ & $0.59(0.27)$ & $0.53(0.28)$ & $0.58(0.16)$ \\
Alcoholic & 77 & $0.66(0.27)$ & $0.61(0.27)$ & $0.52(0.33)$ & $0.59(0.19)$ \\
beverage & 72 & $0.67(0.32)$ & $0.65(0.30)$ & $0.57(0.34)$ & $0.63(0.20)$ \\
Nightlife & 93 & $0.56(0.28)$ & $0.55(0.28)$ & $0.49(0.31)$ & $0.53(0.19)$ \\
Lifestyle & 77 & $0.67(0.27)$ & $0.60(0.29)$ & $0.56(0.32)$ & $0.61(0.21)$ \\
Disease & & & & & \\
Health & 80 & $0.51(0.31)$ & $0.44(0.27)$ & $0.39(0.29)$ & $0.44(0.19)$ \\
\hline
\end{tabular}

${ }^{1}$ Mean of the centrality of the three words. 
category factor $\left(\mathrm{W}=0.831, \mathrm{c}^{2}(27)=44.820, p=0.017\right)$. Thus, the Greenhouse Geisser correction was applied to compute the significance of each effect included in the model. The corresponding correction coefficients were 0.994 for the interaction of position and category, 0.994 for position factor and 0.934 for the category factor.

There was not a significant interaction between time and category factor ( $\mathrm{F}$ $(13.1,3190.3)=1.000, p=0.448)$ a finding suggesting that the evolution of word centrality from the first to the third word was not significantly different among the eight categories. Nevertheless, there was a statistically significant effect of position $\left(\mathrm{F}(1.989,485.3)=4.828, p=0.009\right.$, eta $\left.{ }_{p}^{2}=0.019\right)$ as well as of word category on centrality $\left(\mathrm{F}(6.656,1624.2)=4.197, \mathrm{p}<0.001\right.$, eta $\left._{p}^{2}=0.017\right)$, suggesting significant differences between the three word positions as well as among the eight word categories. Concerning sociodemographic factors, there was not a significant interaction of gender, age, educational level and family status on the centrality evolution from the $1^{\text {st }}$ to $2^{\text {nd }}$ and from the $2^{\text {nd }}$ to the $3^{\text {rd }}$ word, as well as among the eight word categories, a finding indicating that the centrality of the words selected by the participants to describe those eight concepts are not related to their demographic characteristics (Table 2).

The category and the position effects are illustrated at Figure 2. The centralities

Table 2. Two way within-subjects effects (Greenhouse-Geisser correction applied).

\begin{tabular}{|c|c|c|c|c|c|c|}
\hline Source & $\begin{array}{l}\text { Type III Sum } \\
\text { of Squares }\end{array}$ & df & $\begin{array}{l}\text { Mean } \\
\text { Square }\end{array}$ & $\mathbf{F}$ & $\mathrm{p}$ & $\begin{array}{c}\text { Partial } \\
\text { eta }^{2}\end{array}$ \\
\hline position & 0.711 & 1.989 & 0.357 & 4.828 & 0.009 & 0.019 \\
\hline position ${ }^{\star}$ gender & 0.012 & 1.989 & 0.006 & 0.079 & 0.923 & 0.000 \\
\hline position ${ }^{\star}$ married & 0.126 & 1.989 & 0.063 & 0.853 & 0.426 & 0.003 \\
\hline position ${ }^{*}$ education & $6.2 \times 10^{-5}$ & 1.989 & $3.1 \times 10^{-5}$ & 0.000 & 1.000 & 0.000 \\
\hline position ${ }^{\star}$ age & 0.083 & 1.989 & 0.042 & 0.561 & 0.570 & 0.002 \\
\hline Error (position) & 35.921 & 485.289 & 0.074 & & & \\
\hline category & 2.528 & 6.656 & 0.380 & 4.197 & 0.000 & 0.017 \\
\hline category ${ }^{*}$ gender & 0.873 & 6.656 & 0.131 & 1.449 & 0.185 & 0.006 \\
\hline category ${ }^{\star}$ married & 0.608 & 6.656 & 0.091 & 1.009 & 0.421 & 0.004 \\
\hline category ${ }^{\star}$ education & 1.119 & 6.656 & 0.168 & 1.859 & 0.077 & 0.008 \\
\hline category ${ }^{\star}$ age & 1.089 & 6.656 & 0.164 & 1.809 & 0.086 & 0.007 \\
\hline Error(category) & 146.947 & 1624.157 & 0.090 & & & \\
\hline position ${ }^{*}$ category & 1.065 & 13.075 & 0.081 & 1.000 & 0.448 & 0.004 \\
\hline position ${ }^{\star}$ category ${ }^{\star}$ gender & 1.011 & 13.075 & 0.077 & 0.949 & 0.500 & 0.004 \\
\hline position ${ }^{\star}$ category ${ }^{\star}$ married & 0.845 & 13.075 & 0.065 & 0.794 & 0.668 & 0.003 \\
\hline position $^{*}$ category $^{*}$ education & 1.008 & 13.075 & 0.077 & 0.947 & 0.503 & 0.004 \\
\hline position ${ }^{\star}$ category ${ }^{\star}$ age & 0.893 & 13.075 & 0.068 & 0.838 & 0.620 & 0.003 \\
\hline Error (position ${ }^{\star}$ category) & 259.833 & 3190.327 & 0.081 & & & \\
\hline
\end{tabular}




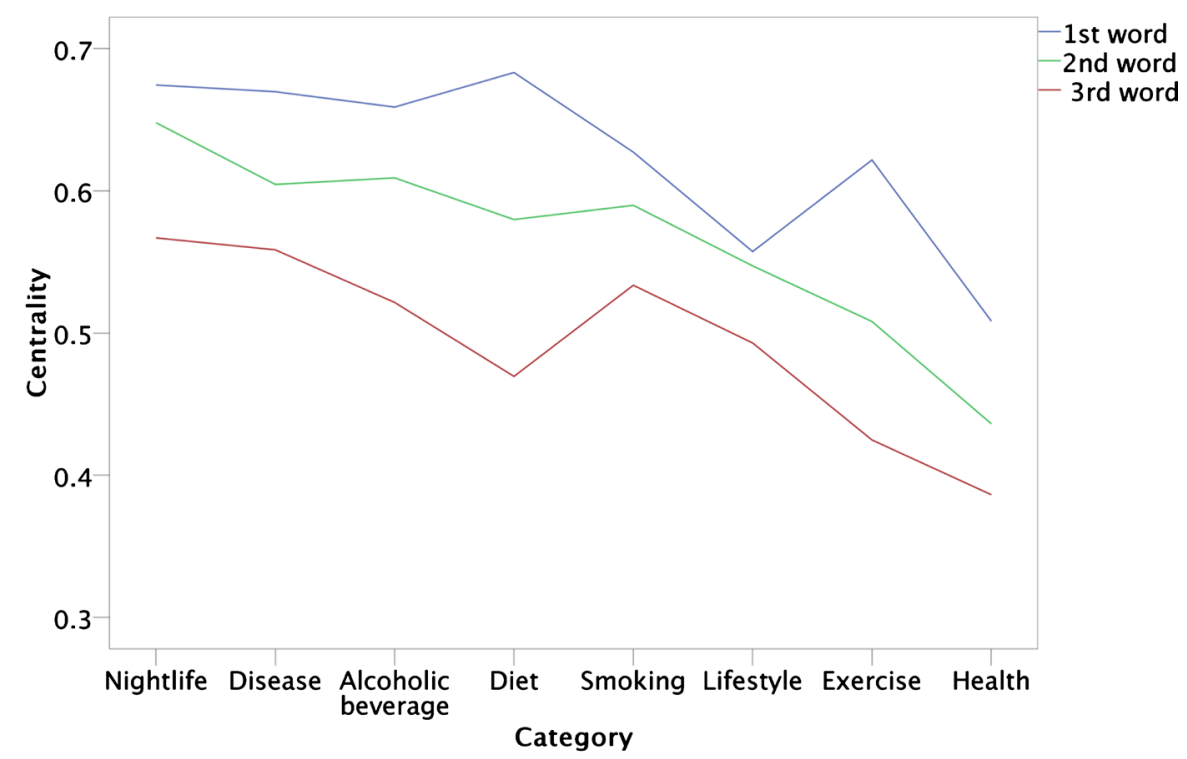

Figure 2. Mean centrality for each category and position.

of the words describing disease and nightlife had the largest values in all three word positions a finding that indicates a larger degree of agreement among the participants about the terms describing the respective human experiences.

In contrary, health was the category with the smallest centrality in all three positions a finding suggesting that there is a greater variety of words expressing this concept. Post hoc paired samples t-tests reveals that the categories of Nightlife, Disease, Alcoholic beverage and Diet form a group with analogous centralities clearly separated in the first spoken word while Health had significantly smaller centrality than most of the other categories in all three words indicating this way greater variety.

The decreasing order of centralities between the three words for all eight categories indicates a uniform tendency of the respondents to choose words through a common set of words, giving more personal and decentralized responses in their $2^{\text {nd }}$ and $3^{\text {rd }}$ try.

Post hoc paired samples t-test reveals that the words concerning Diet and Exercise had a significantly decreasing order between the three words indicating a gradual increase in the individuality of the given characterizations. Concerning Health and Disease categories, it was found that $2^{\text {nd }}$ and $3^{\text {rd }}$ words was significantly decentralized from the $1^{\text {st }}$ provided word but without significant difference between them, a finding that indicates a smaller range of personalized perceptions for that two categories. Responses concerning alcoholic beverages had not significant centrality difference between $1^{\text {st }}$ and $2^{\text {nd }}$ word, but the $3^{\text {rd }}$ word was significantly decentralized. Finally, not significant differences were detected in Smoking, Nightlife, and Lifestyle categories showing that the participants were used a wider range of different words without highlighting specific words with global community agreement (Table 3 ).

Thus, the eight categories are naturally divided into four groups from which 
Table 3. Centrality differences among the three words.

\begin{tabular}{cccccc}
\hline & & Difference M (SD) & t & df & $p^{1}$ \\
\hline Diet & $1^{\text {st }}-2^{\text {nd }}$ & $0.10(0.41)$ & 4.177 & 286 & $<0.001$ \\
& $2^{\text {nd }}-3^{\text {rd }}$ & $0.10(0.38)$ & 4.521 & 286 & $<0.001$ \\
Exercise & $1^{\text {st }}-2^{\text {nd }}$ & $0.11(0.41)$ & 4.583 & 283 & $<0.001$ \\
& $2^{\text {nd }}-3^{\text {rd }}$ & $0.07(0.39)$ & 3.247 & 284 & 0.001 \\
Alcoholic beverage & $1^{\text {st }}-2^{\text {nd }}$ & $0.05(0.36)$ & 2.357 & 281 & 0.019 \\
& $2^{\text {nd }}-3^{\text {rd }}$ & $0.07(0.38)$ & 3.335 & 281 & 0.001 \\
Hisease & $1^{\text {st }}-2^{\text {nd }}$ & $0.07(0.36)$ & 3.222 & 272 & 0.001 \\
& $2^{\text {nd }}-3^{\text {rd }}$ & $0.03(0.37)$ & 1.524 & 272 & 0.129 \\
& $1^{\text {st }}-2^{\text {nd }}$ & $0.07(0.38)$ & 3.012 & 264 & 0.003 \\
& $2^{\text {nd }}-3^{\text {rd }}$ & $0.04(0.37)$ & 1.755 & 264 & 0.080 \\
Smoking & $1^{\text {st }}-2^{\text {nd }}$ & $0.04(0.33)$ & 1.859 & 285 & 0.064 \\
& $2^{\text {nd }}-3^{\text {rd }}$ & $0.05(0.37)$ & 2.139 & 285 & 0.033 \\
Nightlife & $1^{\text {st }}-2^{\text {nd }}$ & $0.03(0.44)$ & 1.134 & 280 & 0.258 \\
& $2^{\text {nd }}-3^{\text {rd }}$ & $0.07(0.44)$ & 2.623 & 280 & 0.009 \\
& $1^{\text {st }}-2^{\text {nd }}$ & $0.01(0.37)$ & 0.380 & 280 & 0.704 \\
& $2^{\text {nd }}-3^{\text {rd }}$ & $0.04(0.39)$ & 1.793 & 280 & 0.074 \\
\hline
\end{tabular}

${ }^{1}$ Significant at level $0.003125(=0.05 / 16-$ Bonferroni correction $)$.

the first contains the social constructs of Diet and Exercise that exhibits strong social representations that are reflected in the large centrality of the first word while offering a greater degree of personalization to differentiate further in the second and third spoken words. Alcoholic beverage is the second group where the first two words are not significantly different offering the necessary personalization in the $3^{\text {rd }}$ word. The third group containing the social constructs of Health and Disease showing a concrete social identity in the first word but with no further ability of personalized description at the $3^{\text {rd }}$ word. Finally, the fourth group contains the social constructs of Smoking, Nightlife and Lifestyle that do not expressed using words of common agreement, a finding that indicates the weak nature of the respective social representation.

\section{Discussion}

The present study contributes to the study of social representations and the reflection on language usage in a sample of modern Greeks, considering the pluralism of Greek language. The finding that the centrality of words decreases from the first to the second and from the second to the third word confirms the view of the language as a symbolic system structured as a significant chain which inevitably becomes more and more personal as it deepens from the level of conscious representations to unconscious personal images. One may argue, thus, that individuals can create a personal mental representation of the situation to 
understand it and communicate about it.

However, there was no uniform intensity of representations for all eight experiences requested by respondents. For the representations related to the "Nightlife" and the "Lifestyle" no statistically significant difference in the centrality of the three words was found, a finding that characterizes them as the least uniform concepts in terms of personal perceptions and feelings. A conclusion which may mean that the social representations concerning the biological human status such as health, disease, and death, have greater homogeneity among the community members, while concepts having their basis in achieving enjoyment like lifestyle, nightlife, and alcohol consumption show greater differentiation as well. A possible explanation could be the fact that the social representation of health and illness are based on a central core (or central system) as proposed by (Abric, 2001), while pleasure concepts are organized around a peripheral system providing more diversity and flexibility than the representations of central system (Abric, 1994b).

The non-significant effect of demographic characteristics and the centrality of the words possibly indicates that language as a construct living in humans at a more general level that covers the pleasure structures, a finding consistent with the psychoanalytical approach that identifies language and unconscious. Lack of gender influence suggests that the structure of language is uniform in all people and is a superset of the symbolic system of pleasure. The statistically insignificant influence of education, marital status, and age indicates that common linguistic representations belong to a social symbol that is adopted by all members of society regardless of education and the duration of language use. Language is particularly emerging as the mediating element allowing the subject to attain recognition from the other (Jacques, 1977).

It is well known that the social representations of health and illness can partly explain the reasons why phenomena such as healthy food attitudes and behaviors, macrobiotics, various types of "mild medicine" and the rapid spread of ecological ideas in technologically advanced countries are emerging (Papastamou, 1989). The work of Lederman et al. (2003) presented examples illustrating how alcohol use is documented in language. An example is the word "hangover", which was found to correspond to consuming five or more drinks at an outing. Recent research has also shown that household income, occupational social class, and educational level are correlated with the type and quality of nourishment (Maguire \& Monsivais, 2015). Furthermore, our results are consistent with the theory of social representations that argues that the individual's perception of his environmental reality is expressed through social representations-called "cognitive and emotional networks" - which are activated in everyday practice in the form of knowledge, ideas, desires, plans, etc. (Riga, 1996).

We could argue that the results of our study, despite its reasonable limitations, can lead to a redefinition of certain views regarding the function of social representations towards health and illness. Future studies could focus on dimensions 
of representations as dynamic sets of shaping and prevailing a psychopathological behavior. Our findings underscored the importance and value of developing new health policies. The growing interest in health beliefs is linked, as mentioned, to broader changes, concerning aspects of health care, health policies, social and cultural structures. Therefore, social scientists need to be aware of these changes. The practical application based on our research approach could be the design of an educational intervention in the field of Primary Health Care, Health Psychology, and Health Sociology within the above framework, which will be adapted to the needs and desires of individuals as they are shaped by the social context in which they are living, communicating, and acting. In other words, a practical application that will emphasize the real desire of oneself and not the desire of others. At the same time, it should develop the critical thinking and attitude of individuals as a means of evaluation and resistance to regulatory standards of health and related behaviors that are projected as smoking, diet, overnight according to the statement of Kirk (1993) that "there is space, cracking in the obvious resilient surface of the regulatory images created by the media, which may leave room for skepticism, doubt, and criticism". We concluded that the understanding of the relationship between social representations of health and the language is intrinsically related to the behavior that language as a common way of communication can bring to psychosomatic health.

\section{Agree to Conditions}

1) All authors of the manuscript have read and agreed to its content and are accountable for all aspects of the accuracy and integrity of the manuscript; 2) The submitted article is original work that is not being considered or reviewed by any other publication, and has not been published elsewhere in the same or a similar form.

\section{Conflicts of Interest}

The authors declare no conflicts of interest regarding the publication of this paper.

\section{References}

Abric, J.-C. (1994a). Les représentations sociales: Aspects théoriques [Social Representations: Theoretical Aspects]. In J.-C. Abric (Ed.), Pratiques sociales et représentations [Social Practices and Representations] (pp. 11-35). Paris: Presses Universitaires de France.

Abric, J.-C. (1994b). Méthodologie de recueil des représentations sociales. In J.-C. Abric (Ed.), Pratiques sociales et representations (pp. 59-82). Paris: Presses Universitaires de France.

Abric, J. C. (1988). L'étude experimentale des représentations sociales. In: Les Representations Sociales. Org.: Denise Jodelet. Paris: PUF.

Abric, J.-C. (2001). A Structural Approach to Social Representations. In K. Deaux, \& G. Philogène (Eds.), Representations of the Social (pp. 42-47). Oxford: Blackwell. 
Alasuutari, P. (1995). Researching Culture: Qualitative Method and Cultural Studies. Thousand Oaks, CA: Sage.

Bonacich, P., \& Lloyd, P. (2001). Eigenvector-Like Measures of Centrality for Asymmetric Relations. Social Networks, 23, 191-201. https://doi.org/10.1016/S0378-8733(01)00038-7

Cardoso, M. H., \& Gormes, R. (2000). Social Representations and History: Theoretical and Methodological Principles for Public Health. Cadernos de Saúde Pública, 16, 499506. https://doi.org/10.1590/S0102-311X2000000200020

Dany, L., Urdapilleta, I., \& Monaco, G. L. (2015). Free Associations and Social Representations: Some Reflections on Rank-Frequency and Importance-Frequency Methods. Quality \& Quantity, 49, 489-507. https://doi.org/10.1007/s11135-014-0005-Z

Derrida, J. (1981). The Double Session. Dissemination (Trans. Barbara Johnson, pp. 173285). Chicago, IL: The University of Chicago Press.

Flick, U. (1998). The Social Construction of Individual and Public Health: Contributions of Social Representation Theory to a Social Science of Health. Social Science Information, 37, 639-662. https://doi.org/10.1177/053901898037004005

Foucault, M. (1971). Orders of Discourse. Social Science Information, 10, 7-30. https://doi.org/10.1177/053901847101000201

Foucault, M. (1972). The Archaeology of Knowledge: Translated from the French by AM Sheridan Smith. New York: Pantheon Books.

Geertz, C. (2000). Deep Play: Notes on the Balinese Cockfight. In L. Crothers, \& C. Lockhart (Eds.), Culture and Politics (pp. 175-201). New York: Palgrave Macmillan. https://doi.org/10.1007/978-1-349-62397-6 10

Herzlich, C. (1973). Health and Illness: A Social Psychological Analysis. London: Academic.

Jacques, L. (1977). Ecrits: A Selection (Trans. Alan Sheridan, pp. 3-9). London and New York: Tavistock Publications and Norton.

Joffe, H. (1995). Social Representations of AIDS: Towards Encompassing Issues of Power. Papers on Social Representations, 4, 29-40.

Kirk, D. (1993). The Body, Schooling and Culture. Victoria, Australia: Deakin 164 University.

Lakoff, G., \& Johnson, M. (2003). Why Cognitive Linguistics Require Embodied Realism. Cognitive Linguistics, 13, 245-264. https://doi.org/10.1515/cogl.2002.016

Lederman, L. C., Stewart, L. P., Goodhart, F. W., \& Laitman, L. (2003). A Case against "Binge" as the Term of Choice: Convincing College Students to Personalize Messages about Dangerous Drinking. Journal of Health Communication, 8, 79-91. https://doi.org/10.1080/10810730305734

Maguire, E. R., \& Monsivais, P. (2015). Socio-Economic Dietary Inequalities in UK Adults: An Updated Picture of Key Food Groups and Nutrients from National Surveillance Data. British Journal of Nutrition, 113, 181-189.

https://doi.org/10.1017/S0007114514002621

Moscovici, S. (1984). Psychologie sociale. Presses: Universitaires de France.

Moscovici, S., \& Hewstone, M. (1984). De la science au sens commun. In S. Moscovici (Ed.), Psychologie sociale. Presses: Universitaires de France.

Moscovici, S., Doise, W., \& Dulong, R. (1972). Studies in Group Decision II: Differences of Position, Differences of Opinion and Group Polarization. European Journal of Social Psychology, 2, 385-399. https://doi.org/10.1002/ejsp.2420020404

Murray, M. (1993). Social and Cognitive Representations of Health and Illness. In H. 
Schroder, K. Reschke, M. Johnston, \& S. Maes (Eds.), Health Psychology: Potential in Diversity (pp. 124-131). Regensburg, Germany: S. Roderer Verlag.

Murray, M. (2002). Connecting Narrative and Social Representation Theory in Health Research. Social Science Information, 41, 653-673. https://doi.org/10.1177/0539018402041004008

Papastamou, S. (1989). Handbook of Social Psychology. Athens: Odysseus.

RC Team (2013). R: A Language and Environment for Statistical Computing. Vienna, Austria. https://www.R-project.org/

Riga, A. B. (1996). Preface to the Greek Edition. In M. Zavalloni, \& C. Louis-Guèrin (Ed.), Social Identity and Consciousness (pp. 11-20). Athens: Ellinika Grammata.

Wickham, H., Averick, M., Bryan, J., Chang, W., McGowan, L. D. A., François, R. et al. (2019). Welcome to the Tidyverse. Journal of Open Source Software, 4, 1686. https://doi.org/10.21105/joss.01686 


\section{Appendix}

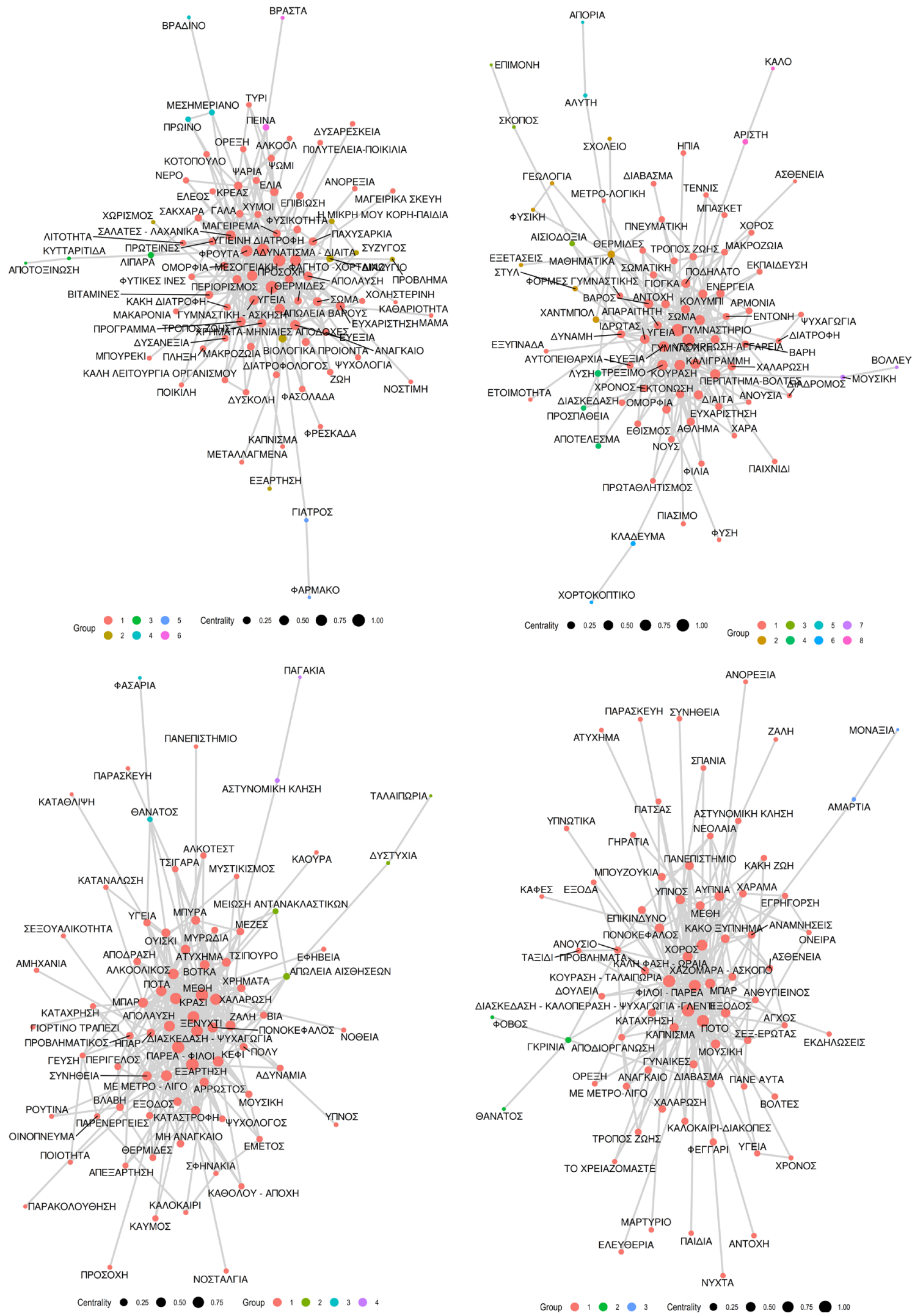

Figure A1. Word graphs for diet, exercise, alcoholic beverages and nightlife (up to down and left to right). 

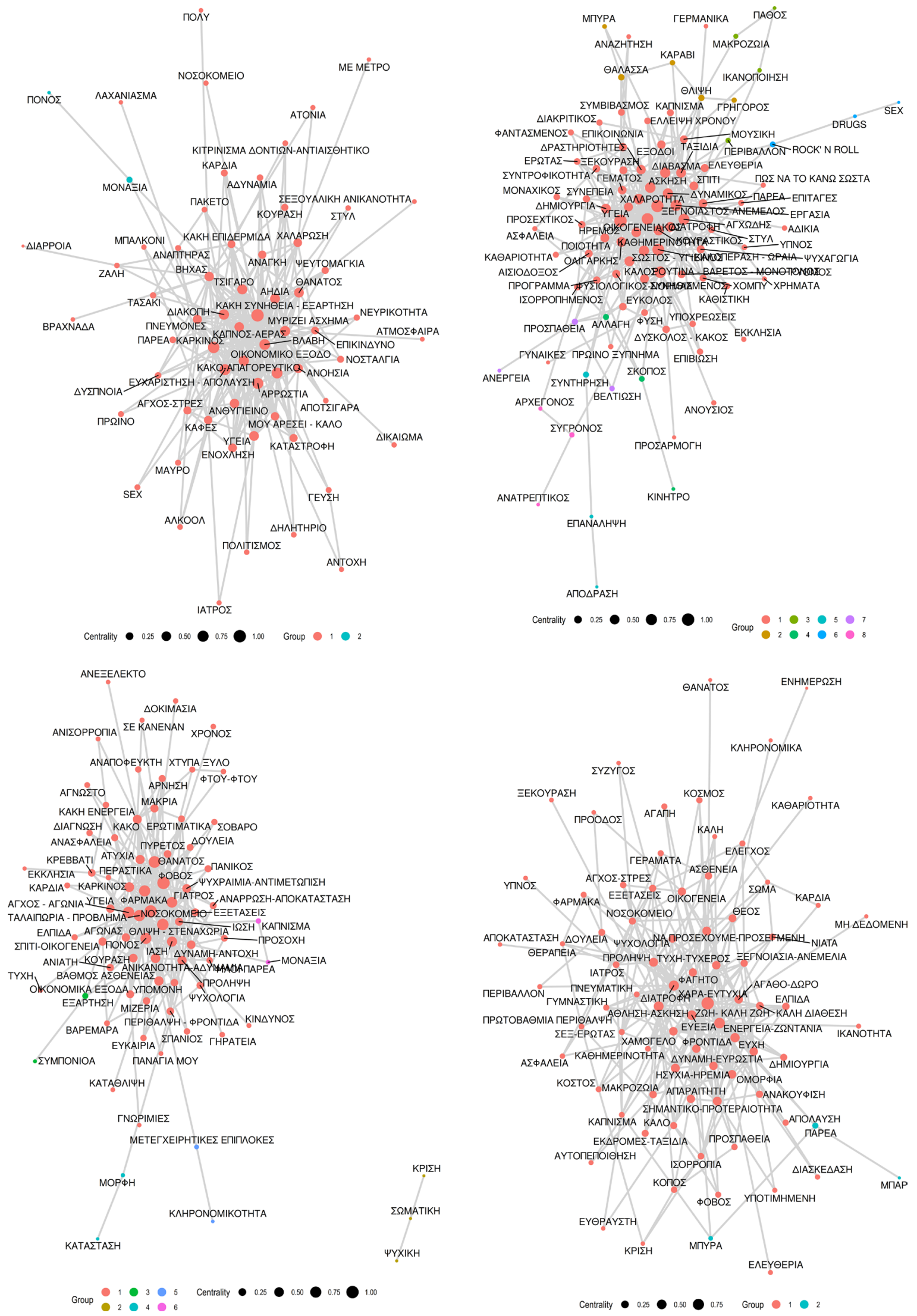

Figure A2. Word graphs for smoking, lifestyle, disease and health (up to down and left to right). 
Table A1. Words that grouped together.

\begin{tabular}{|c|c|c|c|}
\hline $\operatorname{Diet}(\Delta เ \alpha \tau \rho \circ \varphi \dot{\eta})$ & 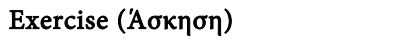 & Smoking (Toı $\alpha \dot{\alpha} \rho o$ ) & Alcoholic beverage (A $\lambda$ коó $\lambda$ ) \\
\hline 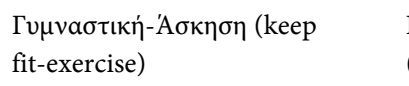 & 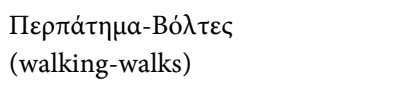 & 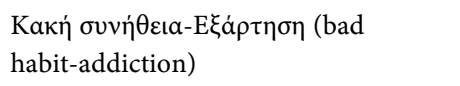 & $\begin{array}{l}\Delta ı \alpha \sigma \kappa \varepsilon \dot{\varepsilon} \alpha \sigma \eta-\Psi v \chi \alpha \gamma \omega \gamma^{\prime} \alpha \\
\text { (amusement-recreation) }\end{array}$ \\
\hline $\begin{array}{l}\sum \alpha \lambda \alpha ́ \tau \varepsilon \varsigma-\Lambda a \chi \alpha \nu ı \kappa \alpha ́ \\
\text { (salads-vegetables) }\end{array}$ & $\begin{array}{l}\Upsilon \pi 0 \chi \rho \varepsilon \dot{\varepsilon} \omega \sigma \eta-A \gamma \gamma \alpha \rho \varepsilon i \alpha \\
\text { (obligation-chore) }\end{array}$ & Mov a & 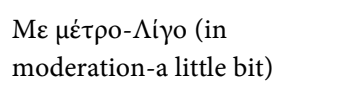 \\
\hline 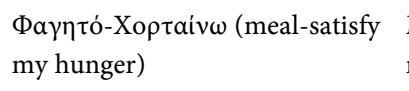 & 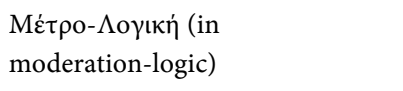 & 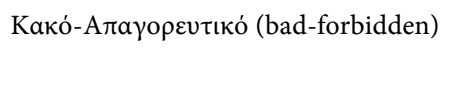 & 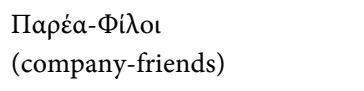 \\
\hline 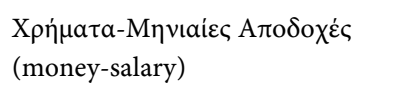 & & 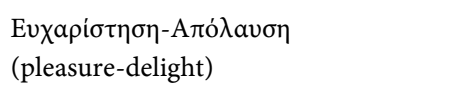 & 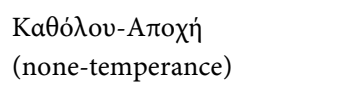 \\
\hline 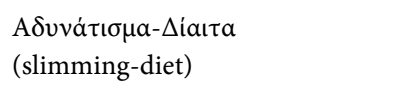 & & 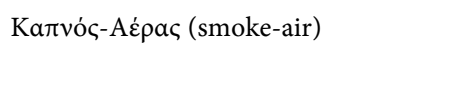 & \\
\hline 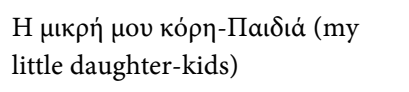 & & 'A $\gamma \chi 0 \varsigma-\Sigma \tau \rho \varepsilon \varsigma$ (anxiety-stress) & \\
\hline \multicolumn{4}{|l|}{$\begin{array}{l}\text { По } \lambda v \tau \varepsilon \dot{\lambda} \lambda \varepsilon ı \alpha-\Pi о \iota \kappa \iota \lambda i \alpha \\
\text { (luxury-variety) }\end{array}$} \\
\hline Nightlife ( $\Xi \varepsilon v u ́ x \tau \iota)$ & 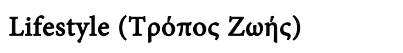 & 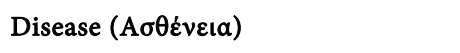 & Health $\left(\Upsilon_{\gamma \varepsilon i \alpha}\right)$ \\
\hline 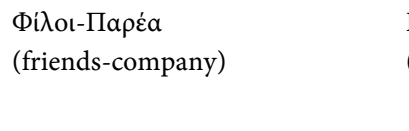 & $\begin{array}{l}\text { Poutiva-Bapєtóc-Movótovoc } \\
\text { (rutine-boring-prosaic) }\end{array}$ & 'A $\gamma \chi \propto \varsigma-A \gamma \omega v i \alpha$ (anxiety-anguish) & 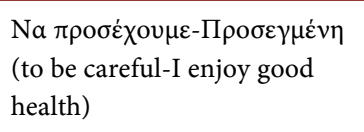 \\
\hline $\begin{array}{l}\Delta ı \sigma \sigma \kappa \varepsilon \delta \alpha \sigma \eta-K a \lambda o \pi \varepsilon \dot{\varepsilon} \rho \sigma \eta-\Psi v \chi \alpha \gamma \\
\omega \gamma i \alpha-\Gamma \lambda \varepsilon \dot{\varepsilon} v \tau \text { (amusement- } \\
\text { have a good time- } \\
\text { recreation-merriment) }\end{array}$ & 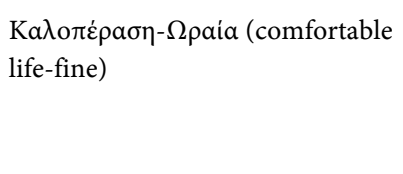 & $\begin{array}{l}\Theta \lambda i \psi \eta-\Sigma \tau \varepsilon v a \chi \omega \dot{\omega}\llcorner\alpha \\
\text { (sadness-tryingness) }\end{array}$ & 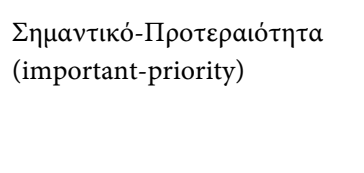 \\
\hline 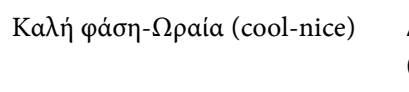 & $\begin{array}{l}\Delta \dot{v} \sigma \kappa о \lambda о \varsigma-\text { Какó } \\
\text { (trying-maleficent) }\end{array}$ & 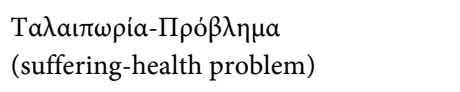 & 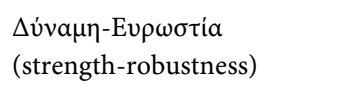 \\
\hline $\begin{array}{l}\text { ХаҺона́ра-'Абколо } \\
\text { (nonsense-aimless) }\end{array}$ & $\begin{array}{l}\sum \omega \sigma \tau o ́ \varsigma-\Upsilon \gamma ı \varepsilon เ v o ́ \varsigma \\
\text { (proper-healthy) }\end{array}$ & 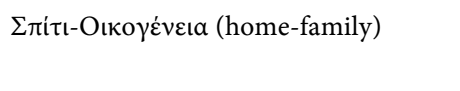 & 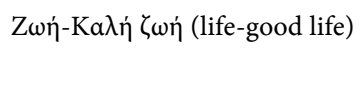 \\
\hline 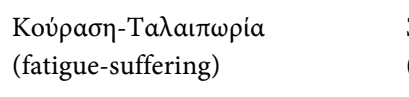 & 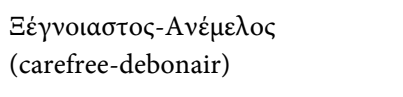 & 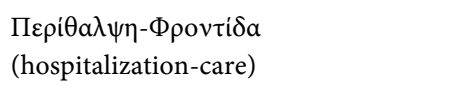 & 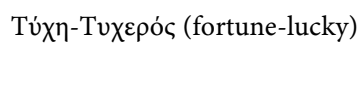 \\
\hline$\Sigma \varepsilon \xi^{\prime}$ E $\rho \omega \tau \alpha \varsigma$ (sex-love) & 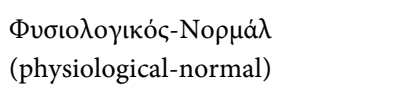 & $\begin{array}{l}\Psi v \chi \rho а \mu \mu i \alpha-A v \tau \iota \mu \varepsilon \tau \omega \dot{\omega} \pi \_\eta \\
\text { (composure-treatment) }\end{array}$ & 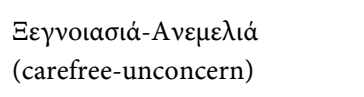 \\
\hline 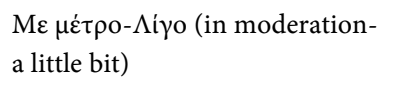 & & $\Delta \dot{v} v \alpha \mu \eta-A v \tau o \chi \eta ่ ~(s t r e n g t h-e n d u r a n c e)$ & $\begin{array}{l}\text { 'A } \theta \lambda \eta \sigma \eta-' A \sigma \kappa \eta \sigma \eta \\
\text { (sports-exercise) }\end{array}$ \\
\hline \multirow[t]{7}{*}{ 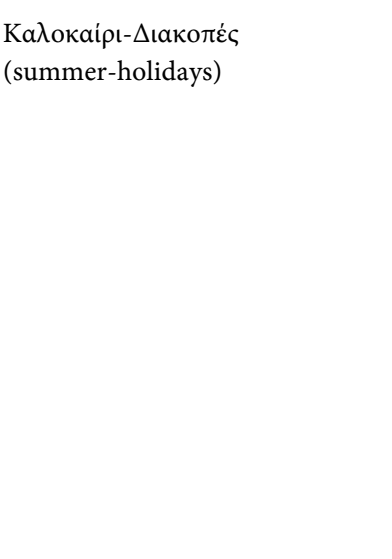 } & & $\begin{array}{l}\text { Avıкavó } \tau \tau \alpha-A \delta v v \alpha \mu i \alpha \\
\text { (inability-weakness) }\end{array}$ & 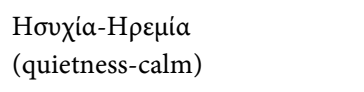 \\
\hline & & $\begin{array}{l}\text { A } v \dot{\alpha} \rho \rho \omega \sigma \eta-A \pi о \kappa \alpha \tau \dot{\alpha} \sigma \tau \alpha \sigma \eta \\
\text { (recovery-restoration) }\end{array}$ & 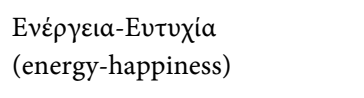 \\
\hline & & Фì⿵ot-Парє́a (friend-company) & 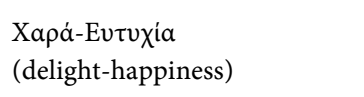 \\
\hline & & & A $\gamma a \theta \dot{o}-\Delta \dot{\omega} \rho o$ (good-boon) \\
\hline & & & $\Sigma \varepsilon \xi$-E $\rho \omega \tau \alpha \varsigma$ (sex-love) \\
\hline & & & 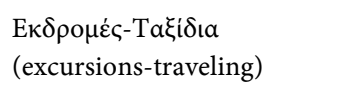 \\
\hline & & & 'A $\gamma \chi \circ \varsigma-\Sigma \tau \rho \varepsilon \varsigma$ (anxiety-stess) \\
\hline
\end{tabular}


Table A2. The 5 words with the largest centrality in each word category.

\begin{tabular}{|c|c|}
\hline 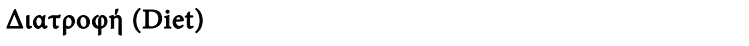 & 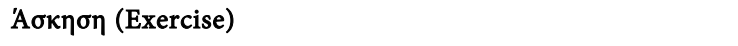 \\
\hline Yүeía (Health), $N=119, \mathrm{c}=1$ & $\Upsilon$ Yzía (Health), $\mathrm{N}=104, \mathrm{c}=1$ \\
\hline 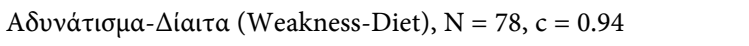 & 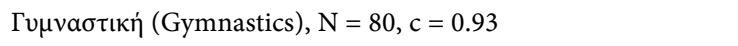 \\
\hline 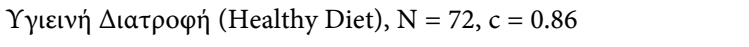 & Eve $\xi i a$ (Wellness), $\mathrm{N}=45, \mathrm{c}=0.65$ \\
\hline Фpoúta (Fruit), $\mathrm{N}=68, \mathrm{c}=0.78$ & Koúpaơ (Fatigue), $\mathrm{N}=42, \mathrm{c}=0.65$ \\
\hline 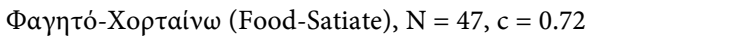 & 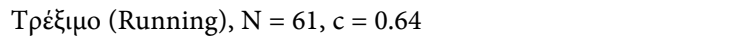 \\
\hline 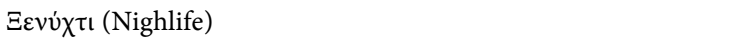 & 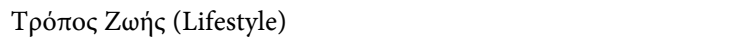 \\
\hline 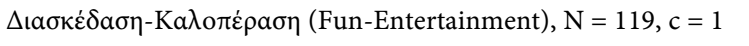 & 'H $\rho \varepsilon \mu \varsigma$ (Quiescent), $\mathrm{N}=68, \mathrm{c}=1$ \\
\hline 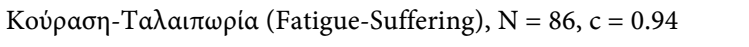 & $\Xi \dot{\varepsilon} \gamma v o \iota \alpha \sigma \tau o \varsigma-A v \varepsilon \dot{\varepsilon} \mu \varepsilon \lambda o \varsigma$ (Carefree), $N=27, c=0.95$ \\
\hline Пóto (Drink), $\mathrm{N}=106, \mathrm{c}=0.93$ & 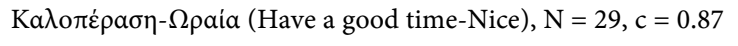 \\
\hline 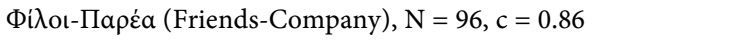 & 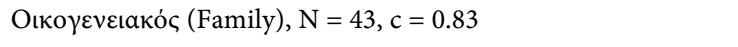 \\
\hline Xopóc (Dance), $\mathrm{N}=33, \mathrm{c}=0.71$ & 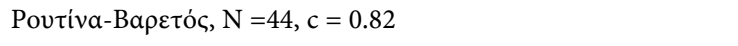 \\
\hline Toıүápo (Smoking) & Потó (Alcoholic Beverage) \\
\hline 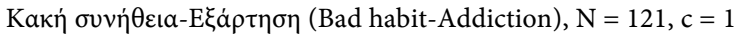 & $\mathrm{E} \xi \dot{\alpha} \rho \tau \eta \sigma \eta$ (Dependence), $\mathrm{N}=58, \mathrm{c}=1$ \\
\hline Kapкívoৎ (Cancer), $\mathrm{N}=74, \mathrm{c}=0.80$ & $M \dot{\theta} \theta \eta$ (Intoxication), $\mathrm{N}=58, \mathrm{c}=0.97$ \\
\hline A $\rho \omega \dot{\omega} \sigma \tau \iota \alpha$ (Sickness), $N=51, c=0.74$ & 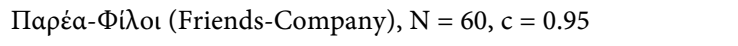 \\
\hline 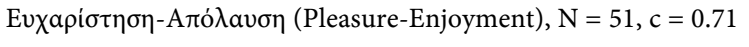 & $\Xi \varepsilon v \dot{\chi} \chi \iota$ (Nightlife), $N=47, c=0.84$ \\
\hline 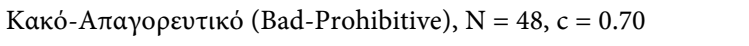 & 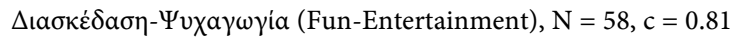 \\
\hline 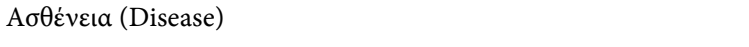 & Yүદía (Health) \\
\hline Фóßoc (Fear), N = 69, c = 0,1 & Xapá-Evтuxía (Joy-Happiness), N = 128, c = 1 \\
\hline Noбоконгіо (Hospital), N = 87, c =0.95 & $Z \omega \eta \dot{n}-K \alpha \lambda \dot{~} \zeta \omega \eta \dot{~(L i f e-G o o d ~ l i f e), ~ N ~=~ 59, ~ c ~=~} 0.66$ \\
\hline 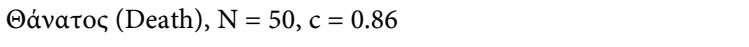 & $\Delta$ เатрочท́ (Diet), $\mathrm{N}=44, \mathrm{c}=0.58$ \\
\hline$\Theta \lambda i \psi \eta-\Sigma \tau \varepsilon v o \chi \omega \dot{\omega}\left\llcorner \_\right.$(Sadness-Distress), $N=28, \mathrm{c}=0.81$ & 'A $\theta \lambda \eta \sigma \eta-A \sigma \kappa \eta \sigma \eta$ (Exercise-Exercise), $\mathrm{N}=41, \mathrm{c}=0.52$ \\
\hline A $\gamma \chi \circ \varsigma$-A $\gamma \omega v i \alpha$ (Death), $N=31, c=0.79$ & Eve $\xi i \alpha$ (Wellness), $\mathrm{N}=38, \mathrm{c}=0.48$ \\
\hline
\end{tabular}

